\title{
The 100 Most Cited Papers About Cancer Epigenetics
}

\author{
Ignacio Jusue-Torres $^{1}$, Joshua E. Mendoza ${ }^{2}$, Malcolm V. Brock ${ }^{3}$, Alicia Hulbert ${ }^{4}$ \\ 1. Neurosurgery, Loyola University Chicago, Stritch School of Medicine, Chicago, USA 2. Sugery, University of Illinois \\ at Chicago, Chicago, USA 3. Surgery, Johns Hopkins University School of Medicine, Baltimore, USA 4. Surgery, \\ University of Illinois at Chicago, Chicago, USA
}

Corresponding author: Alicia Hulbert, ahulbert@uic.edu

\section{Abstract \\ Introduction}

Although bibliometric analyses have been performed in the past on cancer and genomics, little is known about the most frequently cited articles specifically related to cancer epigenetics. Therefore, the purpose of this study is to use citation count to identify those papers in the scientific literature that have made key contributions in the field of cancer epigenetics and identify key driving forces behind future investigations.

\section{Materials and methods}

The Thomas Reuters Web of Science services was queried for the years 1980-2018 without language restrictions. Articles were sorted in descending order of the number of times they were cited in the Web of Science database by other studies, and all titles and abstracts were screened to identify the research areas of the top 100 articles. The number of citations per year was calculated.

\section{Results}

We identified the 100 most-cited articles on cancer epigenetics, which collectively had been cited 147,083 times at the time of this writing. The top-cited article was cited 7,124 times, with an average of 375 citations per year since publication. In the period 1980-2018, the most prolific years were the years 2006 and 2010, producing nine articles, respectively. Twenty-eight unique journals contributed to the 100 articles, with the Nature journal contributing most of the articles $(n=22)$. The most common country of article origin was the United States of America ( $n=78)$, followed by Germany $(n=4)$, Switzerland $(n=4)$, Japan $(n=3)$, Spain $(n=2)$, and United Kingdom ( $\mathrm{n}=2)$.

\section{Conclusions}

In this study, the 100 most-cited articles in cancer epigenetics were examined, and the contributions from various authors, specialties, and countries were identified. Cancer epigenetics is a rapidly growing scientific field impacting translational research in cancer screening, diagnosis, classification, prognosis, and targeted treatments. Recognition of important historical contributions to this field may guide future investigations.

Categories: Genetics, Oncology, Other

Keywords: epigenetic, cancer, molecular biomarker, citation analysis, bibliometrics, dna methylation

\section{Introduction}

In 1942, Conrad Hal Waddington was the first to use the Greek word "epigenesis", to describe how cells differentiated, and thus epigenetics was coined to mean "the causal interactions between genes and their products which bring the phenotype into being" [1]. But it was not until the 1970s when the contemporary definition emerged as "a hereditable change in gene expression that occurred without a change in the DNA sequence" [2]. Broadly speaking, as it applies to modern cancer biology, epigenetics now refers to regulatory mechanisms of DNA transcription that affect gene expression of which DNA methylation is the most widely studied. The relative role of epigenetics in cancer has been attributed to the observation in 1983 by two laboratories that most cancer DNA has fewer methyl groups than non-cancer DNA [3-5]. In one of these studies, Feinberg and Vogelstein showed that DNA methylation was linked to tissue-specific gene silencing in cancer, by finding that a substantial proportion of $\mathrm{CpG}$ islands were methylated in normal tissues were unmethylated in cancer cells [3].

Citation analysis is a systematic approach for identifying scientific publications that have a high impact in the scientific or medical community measuring high-impact papers and how they have shaped scientific disciplines [6]. For this purpose, the Institute for Scientific Information collects citation counts for academic journals in the Science Citation Index. Although bibliometric analyses have been performed in the past on cancer and genomics, little is known about the most frequently cited articles specifically related to cancer 
epigenetics [6-10]. Therefore, the purpose of this study is to use citation count to identify those papers in the scientific literature that have made key contributions in the field of cancer epigenetics and identify key driving forces behind future investigations.

\section{Materials And Methods}

The Thomson Reuters Web of Science (WoS) database was used to query for citations of all articles relevant to cancer epigenetics. The basic search tool was selected, the keyword search for the topic to identify the articles of interest was specified as: "(epigenetic OR epigenomic OR methylation OR hypermethylation OR CpG island OR chromatic remodeling OR histone modification OR RNA interference OR gene silencing OR promoter regions OR chromatin assembly and disassembly OR liquid biopsy OR molecular OR biomolecular) AND (cancer OR neoplasm)". The following search parameters were used: 1) articles published in the years 1980-2018 (since the word "epigenetics" was conceived in 1980); 2) all languages; 3) within the Science Citation Index Expanded. The results were carefully reviewed, and only those relevant to cancer epigenetics were selected. All review articles were excluded from the list. The top 100 articles by the number of citations that matched the search criteria were then further analyzed, and the title, first author, journal, and year of publication, number of citations, country, and the institution of origin were recorded. The articles retrieved were sorted in descending order in terms of times cited, and the number of citations per year was calculated.

\section{Results}

Our query retrieved 234,679 papers (Figure 1).

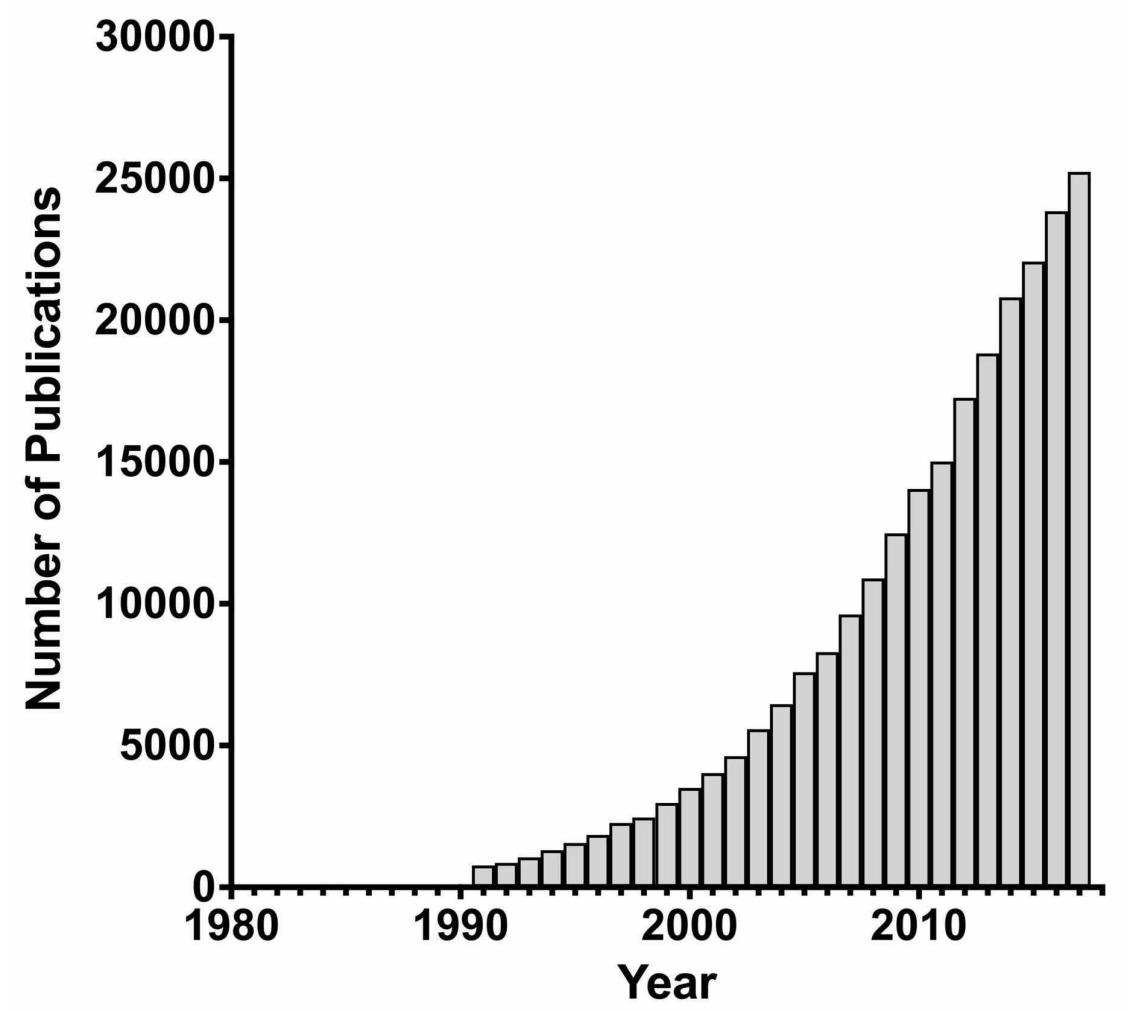

FIGURE 1: Number of publications per year retrieved from the Thomson Reuters Web of Science with the keyword search described in methods

The top 100 articles related to "cancer epigenetics" were identified by the number of times they were cited (Table 1).

\begin{tabular}{|c|c|c|c|c|c|}
\hline $\begin{array}{l}\text { WoS } \\
\text { Rank }\end{array}$ & Authors & Year & Article title & $\begin{array}{l}\text { Total } \\
\text { number } \\
\text { of } \\
\text { citations }\end{array}$ & $\begin{array}{l}\text { CY } \\
\text { index }\end{array}$ \\
\hline 1 & Golub et al. & 1999 & $\begin{array}{l}\text { Molecular classification of cancer: class discovery and class prediction by } \\
\text { gene expression monitoring }\end{array}$ & 7124 & 375 \\
\hline
\end{tabular}




\section{Cureus}

2

Alizadeh et al. 2000 Distinct types of diffuse large B-cell lymphoma identified by gene expression profiling

6045

3 Herman et al. $1996 \begin{aligned} & \text { Methylation-specific PCR: a novel PCR assay for methylation status of CpG } \\ & \text { islands }\end{aligned}$

3 Herman et al. $1996 \begin{aligned} & \text { Methylation-specific PCR: a novel PCR assay for methylation status of CpG } \\ & \text { islands }\end{aligned}$

4 Barski et al. 2007 High-resolution profiling of histone methylations in the human genome

6

Hegi et al. 2005 MGMT gene silencing and benefit from temozolomide in glioblastoma

Comprehensive genomic characterization defines human glioblastoma genes and core pathways

Chin et al.

$$
2008
$$

Cerami et al. 2012

cBio cancer genomics portal: an open platform for exploring

multidimensional cancer genomics data

4600

20926

3849

$350 \quad 10$

3394

$261 \quad 21$

3359

$336 \quad 12$

Effects of radiotherapy with concomitant and adjuvant temozolomide

Stupp et al. 2009 versus radiotherapy alone on survival in glioblastoma in a randomised phase III study: 5-year analysis of the EORTC-NCIC trial

Muzny et al. 2012 Comprehensive molecular characterization of human colon and rectal cancer

Integrated genomic analysis identifies clinically relevant subtypes of NF1

Verhaak et al. 2010 glioblastoma characterized by abnormalities in PDGFRA, IDH1, EGFR, and

Gupta et al. 2010 Long non-coding RNA HOTAIR reprograms chromatin state to promote

cancer metastasis

Forner et al. 2012 Hepatocellular carcinoma

International association for the study of lung cancer/American Thoracic

Travis et al. 2011 Society/European Respiratory Society International Multidisciplinary

Classification of lung adenocarcinoma

Yanaihara et Unique microRNA molecular profiles in lung cancer diagnosis and

al.

2006 prognosis

The genomic and transcriptomic architecture of 2,000 breast tumours

Curtis et al. 2012 reveals novel subgroups

Neve et al.

2006

A collection of breast cancer cell lines for the study of functionally distinct

Nielsen et al.$$
\text { Immunohistochemical and clinical characterization of the basal-like }
$$

subtype of invasive breast carcinoma

Hammerman

et al.

2012 Comprehensive genomic characterization of squamous cell lung cancers

Toyota et al.

$1999 \mathrm{CpG}$ island methylator phenotype in colorectal cancer

Takamizawa

2004

Reduced expression of the let-7 microRNAs in human lung cancers in

et al. association with shortened postoperative survival

$5^{\prime} \mathrm{CpG}$ island methylation is associated with transcriptional silencing of the

Merlo et al tumour suppressor p16/CDKN2/MTS1 in human cancers

Genomic and epigenomic landscapes of adult de novo acute myeloid leukemia

al.

The polycomb group protein EZH2 is involved in progression of prostate

Bhattacharjee et al.

Classification of human lung carcinomas by mRNA expression profiling reveals distinct adenocarcinoma subclasses 


\section{Cureus}

Zhang et al. 2007 microRNAs as oncogenes and tumor suppressors

Kandoth et al. 2013 Mutational landscape and significance across 12 major cancer types

Cameron et 1999 Synergy of demethylation and histone deacetylase inhibition in the re-

al.

1999 expression of genes silenced in cancer

Clark et al. 1994 High sensitivity mapping of methylated cytosines.

Herman et al. 1998 Incidence and functional consequences of hMLH1 promoter hypermethylation in colorectal carcinoma

Bass et al. 2014 Comprehensive molecular characterization of gastric adenocarcinoma

Collisson et

al.

2014 Comprehensive molecular profiling of lung adenocarcinoma

Brennan et al. 2013 The somatic genomic landscape of glioblastoma

Esteller et al. 2000 Inactivation of the DNA-repair gene MGMT and the clinical response of gliomas to alkylating agents

Weinstein et al.

2013 The cancer genome atlas pan-cancer analysis project

Distribution, silencing potential and evolutionary impact of promoter DNA

Weber et al.

$$
2007
$$
methylation in the human genome

Figueroa et 2010 Leukemic IDH1 and IDH2 mutations result in a hypermethylation

al.

phenotype, disrupt TET2 function, and impair hematopoietic differentiation

Getz et al. 2013 Integrated genomic characterization of endometrial carcinoma

The human colon cancer methylome shows similar hypo- and

Irizarry et al.

Herman et al. 1995 Inactivation of the CDKN2/p16/MTS1 gene is frequently associated with aberrant DNA methylation in all common human cancers.

$\mathrm{Rb}$-mediated heterochromatin formation and silencing of E2F target genes

Silencing of the VHL tumor-suppressor gene by DNA methylation in renal carcinoma.

Swerdlow et al.

The 2016 revision of the World Health Organization classification of lymphoid neoplasms

Noushmehr

2010 Identification of a CpG Island methylator phenotype that defines a distinct subgroup of glioma

Methylation of the hMLH1 promoter correlates with lack of expression of

Kane et al. 1997 h tumor cell lines

Weisenberger $\quad \mathrm{CpG}$ island methylator phenotype underlies sporadic microsatellite et al. instability and is tightly associated with BRAF mutation in colorectal cancer

Weber et al. 2005

Chromosome-wide and promoter-specific analyses identify sites of

differential DNA methylation in normal and transformed human cells Loss of acetylation at Lys16 and trimethylation at Lys 20 of histone $\mathrm{H} 4$ is a

Fraga et al

2005 common hallmark of human cancer

MicroRNA-29 family reverts aberrant methylation in lung cancer by

Fabbri et al.

Orom et al.

2010 Long noncoding RNAs with enhancer-like function in human cells 


\begin{tabular}{|c|c|c|c|c|c|c|}
\hline 55 & Jahr et al. & 2001 & $\begin{array}{l}\text { DNA fragments in the blood plasma of cancer patients: quantitations and } \\
\text { evidence for their origin from apoptotic and necrotic cells }\end{array}$ & 1005 & 59 & 82 \\
\hline 56 & Hudson et al. & 2010 & International network of cancer genome projects & 1000 & 125 & 40 \\
\hline 57 & Costello et al. & 2000 & $\begin{array}{l}\text { Aberrant CpG-island methylation has non-random and tumour-type- } \\
\text { specific patterns }\end{array}$ & 994 & 55 & 85 \\
\hline 58 & Gaudet et al. & 2003 & Induction of tumors in mice by genomic hypomethylation & 993 & 66 & 78 \\
\hline 59 & Sharma et al. & 2010 & $\begin{array}{l}\text { A Chromatin-mediated reversible drug-tolerant state in cancer cell } \\
\text { subpopulations }\end{array}$ & 968 & 121 & 44 \\
\hline 60 & Esteller et al. & 1999 & $\begin{array}{l}\text { Inactivation of the DNA repair gene O-6-methylguanine-DNA } \\
\text { methyltransferase by promoter hypermethylation is a common event in } \\
\text { primary human neoplasia }\end{array}$ & 956 & 50 & 92 \\
\hline 61 & Zuber et al. & 2011 & $\begin{array}{l}\text { RNAi screen identifies Brd4 as a therapeutic target in acute myeloid } \\
\text { leukaemia }\end{array}$ & 941 & 134 & 37 \\
\hline 62 & lorio et al. & 2007 & MicroRNA signatures in human ovarian cancer & 937 & 85 & 60 \\
\hline 63 & Dweep et al. & 2011 & $\begin{array}{l}\text { miRWalk - database: prediction of possible miRNA binding sites by } \\
\text { "walking" the genes of three genomes }\end{array}$ & 936 & 134 & 38 \\
\hline 64 & Comijn et al. & 2001 & $\begin{array}{l}\text { The two-handed E box binding zinc finger protein SIP1 downregulates E- } \\
\text { cadherin and induces invasion }\end{array}$ & 933 & 55 & 86 \\
\hline 65 & Issa et al. & 1994 & $\begin{array}{l}\text { Methylation of the oestrogen receptor } \mathrm{CpG} \text { island links aging and neoplasia } \\
\text { in human colon. }\end{array}$ & 925 & 39 & 98 \\
\hline 66 & Kosaka et al. & 2010 & Secretory mechanisms and intercellular transfer of microRNAs in living cells & 920 & 115 & 48 \\
\hline 67 & Saito et al. & 2006 & $\begin{array}{l}\text { Specific activation of microRNA-127 with downregulation of the proto- } \\
\text { oncogene BCL6 by chromatin-modifying drugs in human cancer cells }\end{array}$ & 917 & 76 & 67 \\
\hline 68 & Carroll et al. & 2006 & Genome-wide analysis of estrogen receptor binding sites & 911 & 76 & 68 \\
\hline 69 & Valk et al. & 2004 & Prognostically useful gene-expression profiles in acute myeloid leukemia & 907 & 65 & 79 \\
\hline 70 & $\begin{array}{l}\text { Weinstein et } \\
\text { al. }\end{array}$ & 1997 & $\begin{array}{l}\text { An information-intensive approach to the molecular pharmacology of } \\
\text { cancer }\end{array}$ & 906 & 43 & 95 \\
\hline 71 & $\begin{array}{l}\text { Kantarjian et } \\
\text { al. }\end{array}$ & 2006 & $\begin{array}{l}\text { Decitabine improves patient outcomes in myelodysplastic syndromes - } \\
\text { resuits of a phase III randomized study }\end{array}$ & 899 & 75 & 70 \\
\hline 72 & $\begin{array}{l}\text { Houseman et } \\
\text { al. }\end{array}$ & 2012 & DNA methylation arrays as surrogate measures of cell mixture distribution & 896 & 149 & 31 \\
\hline 73 & Patel et al. & 2014 & $\begin{array}{l}\text { Single-cell RNA-seq highlights intratumoral heterogeneity in primary } \\
\text { glioblastoma }\end{array}$ & 896 & 224 & 25 \\
\hline 74 & West et al. & 2001 & $\begin{array}{l}\text { Predicting the clinical status of human breast cancer by using gene } \\
\text { expression profiles }\end{array}$ & 891 & 52 & 90 \\
\hline 75 & $\begin{array}{l}\text { Turchinovich } \\
\text { et al. }\end{array}$ & 2011 & Characterization of extracellular circulating microRNA & 874 & 125 & 41 \\
\hline 76 & McCabe et al. & 2012 & $\begin{array}{l}\text { EZH2 inhibition as a therapeutic strategy for lymphoma with EZH2- } \\
\text { activating mutations }\end{array}$ & 861 & 144 & 33 \\
\hline 77 & $\begin{array}{l}\text { Dammann et } \\
\text { al. }\end{array}$ & 2000 & $\begin{array}{l}\text { Epigenetic inactivation of a RAS association domain family protein from the } \\
\text { lung tumour suppressor locus } 3 p 21.3\end{array}$ & 855 & 48 & 94 \\
\hline 78 & Turcan et al. & 2012 & $\begin{array}{l}\text { IDH1 mutation is sufficient to establish the glioma hypermethylator } \\
\text { phenotype }\end{array}$ & 854 & 142 & 34 \\
\hline 79 & Rhee et al. & 2002 & DNMT1 and DNMT3b cooperate to silence genes in human cancer cells & 852 & 53 & 89 \\
\hline 80 & $\begin{array}{l}\text { Lapointe et } \\
\text { al. }\end{array}$ & 2004 & $\begin{array}{l}\text { Gene expression profiling identifies clinically relevant subtypes of prostate } \\
\text { cancer }\end{array}$ & 849 & 61 & 81 \\
\hline 81 & Eckhardt et & 2 & DNA methylation profiling of human chromosomes 6,20 and 22 & 847 & 71 & 73 \\
\hline
\end{tabular}




\section{Cureus}

82

$97 \quad$ Doi et al al.

al.

al. al.

Li et al.

al. et al.

al.
Bos et al. Iliopoulos et

links

Genome-wide mapping of polycomb target genes unravels their roles in cell fate transitions

The 2008 WHO classification of lymphoid neoplasms and beyond: evolving concepts and practical applications

Chapman et

Murakami et

Gregoretti et 2002

2011 Initial genome sequencing and analysis of multiple myeloma

2006

Comprehensive analysis of microRNA expression patterns in hepatocellular carcinoma and non-tumorous tissues

Molecular evolution of the histone deacetylase family: Functional

implications of phylogenetic analysis

Causal relationship between the loss of RUNX3 expression and gastric cancer

$\mathrm{Ng}$ et al.

Bibikova et

2009

Differential expression of microRNAs in plasma of patients with colorectal cancer: a potential marker for colorectal cancer screening

2011 High density DNA methylation array with single CpG site resolution

Molecular interplay of the noncoding RNA ANRIL and methylated histone 2010 H3 lysine 27 by polycomb CBX7 in transcriptional silencing of INK4a

Epigenetic inactivation of SFRP genes allows constitutive WNT signaling in

Suzuki et al. 2004 colorectal cancer

Promoter hypermethylation and BRCA1 inactivation in sporadic breast and ovarian tumors

Schlesinger

Shimono et

Polycomb-mediated methylation on Lys27 of histone $\mathrm{H} 3$ pre-marks genes for de novo methylation in cancer

Downregulation of miRNA-200c links breast cancer stem cells with normal stem cells

Differential methylation of tissue- and cancer-specific CpG island shores

2009 distinguishes human induced pluripotent stem cells, embryonic stem cells and fibroblasts

98

Esteller et al.

1999

Detection of aberrant promoter hypermethylation of tumor suppressor genes in serum DNA from non-small cell lung cancer patients

Aberrant methylation of $\mathrm{p} 16$ [INK4a] is an early event in lung cancer and a potential biomarker for early diagnosis
54

87

96

\section{TABLE 1: The top 100 most cited articles in cancer epigenetics ranked by number of times cited}

CY - number of citations per year; WoS - Web of Knowledge

Citations corresponding to WoS rank are located in appendices.

The articles on this top 100 list were cited between 7,124 times (article rank 1) and 720 times (article rank 100). Collectively, the top 100 articles have been cited 147,083 times with a median of 1,050 for each paper, and an interquartile range of 871 - 1610. The oldest article on the top 100 list was from 1993, and the most recent from 2016. In the period 1980-2018, the two most prolific years were 2006 and 2010, with nine articles each among the top 100 most cited articles. In terms of the number of citations per year, the top article had been cited 375 times per year (CY rank number 6). Likewise, the bottom article has been cited 29 times per year (CY rank number 100). A graph of time vs. publication output (Figure 1) indicates that the field of cancer epigenetics has had publications in the range 1994-2014. The most productive decade was 


\section{Cureus}

from 2000 to 2009, producing 49 papers in the Top 100 (Table 2).

Decade of publication

1970-1979

$1980-1989$

1990-1999

2000-2009

2010-2019
No. of articles $(n=100)$

0

0

13

49

27

TABLE 2: Decade of publication of top 100 in cancer epigenetics

The top 100 most cited articles were published in 28 different journals, with the journal Nature contributing the most studies with 22 articles (Table 3). 


\section{Cureus}

\begin{tabular}{|c|c|c|}
\hline Rank & Journal & No. of articles $(n=100)$ \\
\hline 1 & Nature & 22 \\
\hline 2 & Nature Genetics & 15 \\
\hline 3 & Proceedings of the National Academy of Sciences of the United States of America & 10 \\
\hline 4 & Cancer Research & 8 \\
\hline 4 & Cell & 8 \\
\hline 5 & Cancer Cell & 6 \\
\hline 6 & New England Journal of Medicine & 4 \\
\hline 6 & Science & 4 \\
\hline 7 & Blood & 2 \\
\hline 7 & Molecular Cell & 2 \\
\hline 7 & Nucleic Acids Research & 2 \\
\hline 8 & BMC Bioinformatics & 1 \\
\hline 8 & Cancer & 1 \\
\hline 8 & Cancer Discovery & 1 \\
\hline 8 & Clinical Cancer Research & 1 \\
\hline 8 & Developmental Biology & 1 \\
\hline 8 & Genes Development & 1 \\
\hline 8 & Genomics & 1 \\
\hline 8 & Gut & 1 \\
\hline 8 & Journal of the National Cancer Institute & 1 \\
\hline 8 & Journal of Biological Chemistry & 1 \\
\hline 8 & Journal of Biomedical Informatics & 1 \\
\hline 8 & Journal of Molecular Biology & 1 \\
\hline 8 & Journal of Thoracic Oncology & 1 \\
\hline 8 & Lancet & 1 \\
\hline 8 & Lancet Oncology & 1 \\
\hline 8 & Nature Medicine & 1 \\
\hline 8 & Oncogene & 1 \\
\hline
\end{tabular}

\section{TABLE 3: Journals of origin}

Seventy-eight percent of the top 100 most cited papers originated in the United States $(n=78)$. The next five countries with the highest number of articles were Germany $(n=4)$, Switzerland $(n=4)$, Japan $(n=3)$, Spain $(\mathrm{n}=2)$, and United Kingdom $(\mathrm{n}=2)$. Australia, Belgium, Denmark, Israel, Netherlands, China, and South Korea had one article, each among the top 100. Among the 100 most cited papers, there were a total of 77 unique first authors. Collectively, the two authors with the largest number of articles on the top 100 list were Baylin SB and Herman JG with 26 and 20 papers, respectively (Table 4). The next five authors that followed were Getz G, Laird PW, Meyerson M, Sander C, and Weisenberger DJ, each with 13, 12, 12, 12, and 12 articles, respectively. 


\section{Cureus}

\begin{tabular}{|lll|}
\hline Rank & Author & No. of articles $(\mathbf{n}=100)$ \\
\hline 1 & Baylin SB & 26 \\
\hline 2 & Herman JG & 20 \\
\hline 3 & Getz G & 13 \\
4 & Laird PW & 12 \\
4 & Meyerson M & 12 \\
4 & Sander C & 12 \\
\hline 4 & Weisenberger DJ & 12 \\
\hline 5 & Ding L & 11 \\
\hline 5 & Hayes DN & 11 \\
\hline 5 & Lander ES & 11 \\
\hline
\end{tabular}

\section{TABLE 4: Top five authors appearing in top 100 list}

Among the top 100 cited papers, there were three clinical trials, two guidelines or society-based recommendations, 18 cancer classifications, 11 articles related to research tools or methods, 55 articles related to epigenetic cancer mechanism, nine papers related to epigenetic cancer markers/screening/diagnosis and five papers related to epigenetics and cancer treatment (Table 5).

\begin{tabular}{|c|c|c|c|c|}
\hline $\begin{array}{l}\text { WoS } \\
\text { citation } \\
\text { rank }\end{array}$ & Authors & Year & Article title & $\begin{array}{l}\text { Total } \\
\text { number of } \\
\text { citations }\end{array}$ \\
\hline \multicolumn{5}{|c|}{ CLINICAL TRIALS (n=3) } \\
\hline 5 & Hegi et al. & 2005 & MGMT gene silencing and benefit from temozolomide in glioblastoma & 3394 \\
\hline 8 & Stupp et al. & 2009 & $\begin{array}{l}\text { Effects of radiotherapy with concomitant and adjuvant temozolomide versus } \\
\text { radiotherapy alone on survival in glioblastoma in a randomised phase III study: } 5 \text {-year } \\
\text { analysis of the EORTC-NCIC trial }\end{array}$ & 3252 \\
\hline 71 & $\begin{array}{l}\text { Kantarjian et } \\
\text { al. }\end{array}$ & 2006 & $\begin{array}{l}\text { Decitabine improves patient outcomes in myelodysplastic syndromes - Resuits of a } \\
\text { Phase III randomized study }\end{array}$ & 899 \\
\hline \multicolumn{5}{|c|}{ GUIDELINES OR SOCIETY-BASED RECOMMENDATIONS ( $\mathrm{n}=3$ ) } \\
\hline 14 & Travis et al. & 2011 & $\begin{array}{l}\text { International association for the study of lung cancer/American Thoracic } \\
\text { Society/European Respiratory Society International Multidisciplinary Classification of } \\
\text { lung adenocarcinoma }\end{array}$ & 2225 \\
\hline 56 & Hudson et al. & 2010 & International network of cancer genome projects & 1000 \\
\hline \multicolumn{5}{|c|}{ CLASSIFICATIONS ( $n=18)$} \\
\hline 1 & Golub et al. & 1999 & $\begin{array}{l}\text { Molecular classification of cancer: class discovery and class prediction by gene } \\
\text { expression monitoring }\end{array}$ & 7124 \\
\hline 2 & Alizadeh et al. & 2000 & Distinct types of diffuse large B-cell lymphoma identified by gene expression profiling & 6045 \\
\hline 10 & Verhaak et al. & 2010 & $\begin{array}{l}\text { Integrated genomic analysis identifies clinically relevant subtypes of glioblastoma } \\
\text { characterized by abnormalities in PDGFRA, IDH1, EGFR, and NF1 }\end{array}$ & 2891 \\
\hline 16 & Curtis et al. & 2012 & $\begin{array}{l}\text { The genomic and transcriptomic architecture of } 2,000 \text { breast tumours reveals novel } \\
\text { subgroups }\end{array}$ & 1911 \\
\hline 17 & Neve et al. & 2006 & $\begin{array}{l}\text { A collection of breast cancer cell lines for the study of functionally distinct cancer } \\
\text { subtypes }\end{array}$ & 1828 \\
\hline
\end{tabular}




\section{Cureus}

Toyota et al. $1999 \mathrm{CpG}$ island methylator phenotype in colorectal cancer

Ley et al. 2013 Genomic and epigenomic landscapes of adult de novo acute myeloid leukemia

Classification of human lung carcinomas by mRNA expression profiling reveals distinct adenocarcinoma subclasses

Kandoth et al. 2013 Mutational landscape and significance across 12 major cancer types

Brennan et al. 2013 The somatic genomic landscape of glioblastoma

2010 Leukemic IDH1 and IDH2 mutations result in a hypermethylation phenotype, disrupt

al.

Swerdlow et al.

Noushmehr et al.

Weisenberger et al.

Turcan et al. Lapointe et al.

The
TET2 function, and impair hematopoietic differentiation

2016 The 2016 revision of the World Health Organization classification of lymphoid neoplasms

Identification of a $\mathrm{CpG}$ island methylator phenotype that defines a distinct subgroup of glioma

$\mathrm{CpG}$ island methylator phenotype underlies sporadic microsatellite instability and is tightly associated with BRAF mutation in colorectal cancer

\section{RESEARCH TOOLS/METHODS $(n=11)$}

3 Herman et al. 1996 Methylation-specific PCR: a novel PCR assay for methylation status of CpG islands

High-resolution profiling of histone methylations in the human genome

2012 The cBio cancer genomics portal: an open platform for exploring multidimensional cancer genomics data

High sensitivity mapping of methylated cytosines. al.

2013 The cancer genome Atlas Pan-Cancer analysis project

Chromosome-wide and promoter-specific analyses identify sites of differential DNA methylation in normal and transformed human cells miRWalk - database: prediction of possible miRNA binding sites by "walking" the genes of three genomes

1997 An information-intensive approach to the molecular pharmacology of cancer

al.

2012 DNA methylation arrays as surrogate measures of cell mixture distribution

2011 Characterization of extracellular circulating microRNA al.

2011 High density DNA methylation array with single CpG site resolution

EPIGENETIC CANCER MARKERS/SCREENING/DIAGNOSIS $(n=9)$

15 Yanaihara et al. kamizawa et al.
2006 Unique microRNA molecular profiles in lung cancer diagnosis and prognosis

Reduced expression of the let-7 microRNAs in human lung cancers in association with shortened postoperative survival 


\section{Cureus}

DNA fragments in the blood plasma of cancer patients: quantitations and evidence for their origin from apoptotic and necrotic cells

Belinsky et al.
2009 porsion of microRNAs in plasma

Detection of aberrant promoter hypermethylation of tumor suppressor genes in serum DNA from non-small cell lung cancer patients

Aberrant methylation of $\mathrm{p} 16$ (INK4a) is an early event in lung cancer and a potential biomarker for early diagnosis

\section{EPIGENETIC CANCER TREATMENT $(n=5)$}

Hegi et al.

2005 MGMT gene silencing and benefit from temozolomide in glioblastoma

Effects of radiotherapy with concomitant and adjuvant temozolomide versus

Stupp et al.

2009

radiotherapy alone on survival in glioblastoma in a randomised phase III study: 5-year analysis of the EORTC-NCIC trial

61

Zuber et al.

RNAi screen identifies Brd4 as a therapeutic target in acute myeloid leukaemia

Decitabine improves patient outcomes in myelodysplastic syndromes - resuits of a phase III randomized study

TABLE 5: The top 100 most cited articled in cancer epigenetics categorized by review, clinical trials, guidelines of society-based recommendations, classifications, research tools/methods, epigenetic mechanisms, epigenetic markers/screening/diagnosis, and epigenetic cancer treatment

WoS - Web of Knowledge

Citations corresponding to WoS rank are located in appendices.

\section{Discussion}

In this study, we sought to identify the most cited 100 articles regarding cancer epigenetics, to gain insight into the history and future directions of this rapidly growing scientific field.

The article that received the most citations on the top 100 list was "Molecular classification of cancer: class discovery and class prediction by gene expression monitoring” [11]. This paper was cited 7,340 times, with an average of 408 citations per year since publication. At the time, the paper was notable for developing the first generalized approach for identifying new cancer classes by applying gene expression profiling to distinguish between acute myeloid leukemia (AML) versus acute lymphoblastic leukemia (ALL). This study marked the beginning of gene expression-based cancer therapy. Currently, the European LeukemiaNet classification in AML uses cytogenetic and molecular data to identify the AML prognostic groups [12-14].

Since the first epigenetic abnormality was identified in cancer cells in 1983, multiple advances led to improved knowledge in epigenetics and cancer [3-5]. DNA methylation has been defined as an example of epigenetic dysregulation in cancer, with both hypomethylation and hyper-methylation having significant roles. DNA hypomethylation can lead to gene activation, and it is linked to chromosomal instability [15, 16]. DNA hypermethylation has been associated with gene silencing as a tumor-suppressor silencing cancer mechanism given that it has been found when genes are rarely mutated but that are frequently DNA hypermethylated and silenced in cancer [17-20]. Histone modification is another epigenetic cancer-linked mechanism that controls chromatin structure [21, 22]. As a result, the detection of epigenetic changes, such as abnormal promoter $\mathrm{CpG}$ island DNA hypermethylation, has been studied as a potential biomarker strategy for assessing cancer risk, early detection, prognosis and predicting therapeutic responses [23, 24]. The list of potential marker genes, knowledge of their position in cancer progression, and the development of ever more sensitive epigenetic detection strategies, including nanotechnology approaches, are all expanding $[25,26]$. All these landmark discoveries led to the elucidation of novel cancer biomolecular 
mechanisms, new scientific research tools, and the development of new epigenetic-based targeted therapeutic avenues. As a result of that, "The National Institutes of Health (NIH) Roadmap Epigenomics Mapping Consortium" is accelerating the understanding of epigenomics in human health and disease together with the ENCODE Project (ENCyclopedia Of DNA Elements) [27, 28]. The most immediate future of this new exciting scientific field includes the development of liquid biopsies, personalized medicine, and targeted therapies.

Although citation analysis is a useful tool with the potential benefit of insight into literature trends, it is not without limitations. Over half a century has passed since the Science Citation Index (SCI) was launched as the first systematic effort to track citations in the scientific literature [29]. We recognize that citation counts have inherent biases and that they are not purely quantifiable systems to rank papers by their impact in the scientific literature. In an attempt to control for some of these inherent and potential biases, we utilized the citations per year index in addition to the total number of citations per paper. Despite that, older publications have had a longer timespan to accumulate citations giving them a distinct advantage over newer and potentially more relevant studies. Lastly, one hundred is an arbitrary number since the landmark articles in epigenetic research did not accumulate enough citations such as the paper by Gama-Sosa, Slagel, Trewyn, et al. "The 5-methylcytosine content of DNA from human tumors" that only had 574 citations [30]. Although metrics such as citation counts do have flaws, in the current era, they also serve as one way to measure objectively impact of an article in the scientific community.

\section{Conclusions}

In this study, the 100 most cited articles in cancer epigenetics were examined, and the contributions from various authors, specialties, and countries were identified. Cancer epigenetics is a rapidly growing scientific field impacting translational research in cancer screening, diagnosis, classification, prognosis, and targeted treatments. Recognition of important historical contributions to this field may guide future investigations.

\section{Appendices}

\section{References from Table 1 and Table 5}

1. Golub TR, Slonim DK, Tamayo P, et al.: Molecular classification of cancer: class discovery and class prediction by gene expression monitoring. Science. 1999, 286:531-537. 10.1126/science.286.5439.531

2. Alizadeh AA, Eisen MB, Davis RE, et al.: Distinct types of diffuse large B-cell lymphoma identified by gene expression profiling. Nature. 2000, 403:503-511. 10.1038/35000501

3. Herman JG, Graff JR, Myohanen S, Nelkin BD, Baylin SB: Methylation-specific PCR: a novel PCR assay for methylation status of CpG islands. P Natl Acad Scad USA. 1996, 93:9821-9826. 10.1073/pnas.93.18.9821

4. Barski A, Cuddapah S, Cui K, et al.: High-resolution profiling of histone methylations in the human genome. Cell. 2007, 129:823-837. 10.1016/j.cell.2007.05.009

5. Hegi ME, Diserens AC, Gorlia T, et al.: MGMT gene silencing and benefit from temozolomide in glioblastoma. N Engl J Med. 2005, 352:997-1003. 10.1056/NEJMoa043331

6. Cancer Genome Atlas Research Network: Comprehensive genomic characterization defines human glioblastoma genes and core pathways. Nature. 2008, 455:1061-1068. 10.1038/nature07385

7. Cerami E, Gao J, Dogrusoz U, et al.: The cBio cancer genomics portal: an open platform for exploring multidimensional cancer genomics data. Cancer Discov. 2012, 2:401-404. 10.1158/2159-8290.CD-12-0095

8. Stupp R, Hegi ME, Mason WP, etal.: Effects of radiotherapy with concomitant and adjuvant temozolomide versus radiotherapy alone on survival in glioblastoma in a randomised phase III study: 5-year analysis of the EORTC-NCIC trial. Lancet Oncol. 2009, 10:459-466. 10.1016/S1470-2045(09)70025-7

9. Cancer Genome Atlas Network: Comprehensive molecular characterization of human colon and rectal cancer. Nature. 2012, 487:330-337. 10.1038/nature11252

10. Verhaak RG, Hoadley KA, Purdom E, et al.: Integrated genomic analysis identifies clinically relevant subtypes of glioblastoma characterized by abnormalities in PDGFRA, IDH1, EGFR, and NF1. Cancer Cell. 2010, 17:98-110. 10.1016/j.ccr.2009.12.020

11. Cancer Genome Atlas Research Network: Integrated genomic analyses of ovarian carcinoma. Nature. 2011, 474:609-615. 10.1038/nature10166

12. Gupta RA, Shah N, Wang KC, et al.: Long non-coding RNA HOTAIR reprograms chromatin state to promote cancer metastasis. Nature. 2010, 464:1071-1076. 10.1038/nature08975 
13. Forner A, Llovet JM, Bruix J: Hepatocellular carcinoma. The Lancet. 2012, 379:1245-1255. 10.1016/s01406736(11)61347-0

14. Travis WD, Brambilla E, Noguchi M, et al.: International association for the study of lung cancer/american thoracic society/european respiratory society international multidisciplinary classification of lung adenocarcinoma. J Thorac Oncol. 2011, 6:244-285. 10.1097/JTO.0b013e318206a221

15. Yanaihara N, Caplen N, Bowman E, et al.: Unique microRNA molecular profiles in lung cancer diagnosis and prognosis. Cancer Cell. 2006, 9:189-198. 10.1016/j.ccr.2006.01.025

16. Curtis C, Shah SP, Chin SF, et al.: The genomic and transcriptomic architecture of 2,000 breast tumours reveals novel subgroups. Nature. 2012, 486:346-352. 10.1038/nature10983

17. Neve RM, Chin K, Fridlyand J, et al.: A collection of breast cancer cell lines for the study of functionally distinct cancer subtypes. Cancer Cell. 2006, 10:515-527. 10.1016/j.ccr.2006.10.008

18. Nielsen TO, Hsu FD, Jensen K, et al.: Immunohistochemical and clinical characterization of the basal-like subtype of invasive breast carcinoma. Clin Cancer Res. 2004, 10:5367-5374. 10.1158/1078-0432.CCR-040220

19. Cancer Genome Atlas Research Network: Comprehensive genomic characterization of squamous cell lung cancers. Nature. 2012, 489:519-525. 10.1038/nature11404

20. Toyota M, Ahuja N, Ohe-Toyota M, Herman JG, Baylin SB, Issa JP: CpG island methylator phenotype in colorectal cancer. P Natl Acad Scad USA. 1999, 96:8681-8686. 10.1073/pnas.96.15.8681

21. Takamizawa J, Konishi H, Yanagisawa K, et al.: Reduced expression of the let-7 microRNAs in human lung cancers in association with shortened postoperative survival. Cancer Res. 2004, 64:3753-3756. 10.1158/0008-5472.CAN-04-0637

22. Merlo A, Herman JG, Mao L, et al.: 5' CpG island methylation is associated with transcriptional silencing of the tumour suppressor p16/CDKN2/MTS1 in human cancers. Nat Med. 1995, 1:686-692. 10.1038/nm0795686

23. Cancer Genome Atlas Research Network, Ley TJ, Miller C, et al.: Genomic and epigenomic landscapes of adult de novo acute myeloid leukemia. N Engl J Med. 2013, 368:2059-2074. 10.1056/NEJMoa1301689

24. Varambally S, Dhanasekaran SM, Zhou M, et al.: The polycomb group protein EZH2 is involved in progression of prostate cancer. Nature. 2002, 419:624-629. 10.1038/nature01075

25. Bhattacharjee A, Richards WG, Staunton J, et al.: Classification of human lung carcinomas by mRNA expression profiling reveals distinct adenocarcinoma subclasses. P Natl Acad Scad USA. 2001, 98:1379013795. 10.1073/pnas.191502998

26. Esteller M, Corn PG, Baylin SB, Herman JG: A gene hypermethylation profile of human cancer. Cancer Res. 2001, 61:3225-3229.

27. Meissner A, Mikkelsen TS, Gu H, Wet al.: Genome-scale DNA methylation maps of pluripotent and differentiated cells. Nature. 2008, 454:766-770. 10.1038/nature07107

28. Zhang B, Pan X, Cobb GP, Anderson TA: microRNAs as oncogenes and tumor suppressors. Dev Biol. 2007, 302:1-12. 10.1016/j.ydbio.2006.08.028

29. Kandoth C, McLellan MD, Vandin F, et al.: Mutational landscape and significance across 12 major cancer types. Nature. 2013, 502:333-339. 10.1038/nature12634

30. Cameron EE, Bachman KE, Myohanen S, Herman JG, Baylin SB: Synergy of demethylation and histone deacetylase inhibition in the re-expression of genes silenced in cancer. Nat Genet. 1999, 21:103-107. $10.1038 / 5047$

31. Clark SJ, Harrison J, Paul CL, Frommer M: High sensitivity mapping of methylated cytosines. Nucleic Acids Res. 1994, 22:2990-2997. 10.1093/nar/22.15.2990

32. Herman JG, Umar A, Polyak K, et al.: Incidence and functional consequences of hMLH1 promoter hypermethylation in colorectal carcinoma. P Natl Acad Scad USA. 1998, 95:6870-6875.

10.1073/pnas.95.12.6870 
33. Cancer Genome Atlas Research Network: Comprehensive molecular characterization of gastric adenocarcinoma. Nature. 2014, 513:202-209. 10.1038/nature13480

34. Cancer Genome Atlas Research Network: Comprehensive molecular profiling of lung adenocarcinoma. Nature. 2014, 511:543-550. 10.1038/nature13385

35. Brennan CW, Verhaak RG, McKenna A, et al.: The somatic genomic landscape of glioblastoma. Cell. 2013, 155:462-477. 10.1016/j.cell.2013.09.034

36. Esteller M, Garcia-Foncillas J, Andion E, et al.: Inactivation of the DNA-repair gene MGMT and the clinical response of gliomas to alkylating agents. N Engl J Med. 2000, 343:1350-1354.

10.1056/NEJM200011093431901

37. Cancer Genome Atlas Research Network, Weinstein JN, Collisson EA, et al.: The Cancer Genome Atlas Pan-Cancer analysis project. Nat Genet. 2013, 45:1113-1120. 10.1038/ng.2764

38. Weber M, Hellmann I, Stadler MB, Ramos L, Paabo S, Rebhan M, Schubeler D: Distribution, silencing potential and evolutionary impact of promoter DNA methylation in the human genome. Nat Genet. 2007, 39:457-466. 10.1038/ng1990

39. Figueroa ME, Abdel-Wahab O, Lu C, et al.: Leukemic IDH1 and IDH2 mutations result in a hypermethylation phenotype, disrupt TET2 function, and impair hematopoietic differentiation. Cancer Cell. 2010, 18:553-567. 10.1016/j.ccr.2010.11.015

40. Cancer Genome Atlas Research Network, Kandoth C, Schultz N, et al.: Integrated genomic characterization of endometrial carcinoma. Nature. 2013, 497:67-73. 10.1038/nature12113

41. Irizarry RA, Ladd-Acosta C, Wen B, et al.: The human colon cancer methylome shows similar hypo- and hypermethylation at conserved tissue-specific CpG island shores. Nat Genet. 2009, 41:178-186. 10.1038/ng.298

42. Herman JG, Merlo A, Mao L, et al.: Inactivation of the Cdkn2/P16/Mts1 gene is frequently associated with aberrant DNA methylation in all common human cancers. Cancer Res. 1995, 55:4525-4530.

43. Narita M, Nunez S, Heard E, et al.: Rb-mediated heterochromatin formation and silencing of E2F target genes during cellular senescence. Cell. 2003, 113:703-716. 10.1016/s0092-8674(03)00401-X

44. Herman JG, Latif F, Weng Y, et al.: Silencing of the VHL tumor-suppressor gene by DNA methylation in renal carcinoma. P Natl Acad Scad USA. 1994, 91:9700-9704. 10.1073/pnas.91.21.9700

45. Swerdlow SH, Campo E, Pileri SA, et al.: The 2016 revision of the World Health Organization classification of lymphoid neoplasms. Blood. 2016, $127: 2375-2390.10 .1182 /$ blood-2016-01-643569

46. Noushmehr H, Weisenberger DJ, Diefes K, et al.: Identification of a CpG island methylator phenotype that defines a distinct subgroup of glioma. Cancer Cell. 2010, 17:510-522. 10.1016/j.ccr.2010.03.017

47. Kane MF, Loda M, Gaida GM, et al.: Methylation of the hMLH1 promoter correlates with lack of expression of hMLH1 in sporadic colon tumors and mismatch repair-defective human tumor cell lines. Cancer Res. 1997, 57:808-811.

48. Weisenberger DJ, Siegmund KD, Campan M, et al.: CpG island methylator phenotype underlies sporadic microsatellite instability and is tightly associated with BRAF mutation in colorectal cancer. Nat Genet. 2006, 38:787-793. 10.1038/ng1834

49. Weber M, Davies JJ, Wittig D, Oakeley EJ, Haase M, Lam WL, Schubeler D: Chromosome-wide and promoter-specific analyses identify sites of differential DNA methylation in normal and transformed human cells. Nat Genet. 2005, 37:853-862. 10.1038/ng1598

50. Fraga MF, Ballestar E, Villar-Garea A, et al.: Loss of acetylation at Lys16 and trimethylation at Lys20 of histone H4 is a common hallmark of human cancer. Nat Genet. 2005, 37:391-400. 10.1038/ng1531

51. Fabbri M, Garzon R, Cimmino A, et al.: MicroRNA-29 family reverts aberrant methylation in lung cancer by targeting DNA methyltransferases 3A and 3B. P Natl Acad Scad USA. 2007, 104:15805-15810. 10.1073/pnas.0707628104

52. Orom UA, Derrien T, Beringer M, et al.: Long noncoding RNAs with enhancer-like function in human 
cells. Cell. 2010, 143:46-58. 10.1016/j.cell.2010.09.001

53. Kleer CG, Cao Q, Varambally S, et al.: EZH2 is a marker of aggressive breast cancer and promotes neoplastic transformation of breast epithelial cells. P Natl Acad Scad USA. 2003, 100:11606-11611. 10.1073/pnas. 1933744100

54. Cancer Genome Atlas Research Network: Comprehensive molecular characterization of urothelial bladder carcinoma. Nature. 2014, 507:315-322. 10.1038/nature12965

55. Jahr S, Hentze H, Englisch S, Hardt D, Fackelmayer FO, Hesch RD, Knippers R: DNA fragments in the blood plasma of cancer patients: Quantitations and evidence for their origin from apoptotic and necrotic cells. Cancer Res. 2001, 61:1659-1665.

56. International Cancer Genome Consortium, Hudson TJ, Anderson W, et al.: International network of cancer genome projects. Nature. 2010, 464:993-998. 10.1038/nature08987

57. Costello JF, Fruhwald MC, Smiraglia DJ, et al.: Aberrant CpG-island methylation has non-random and tumour-type-specific patterns. Nat Genet. 2000, 24:132-138. 10.1038/72785

58. Gaudet F, Hodgson JG, Eden A, et al.: Induction of tumors in mice by genomic hypomethylation. Science. 2003, 300:489-492. 10.1126/science.1083558

59. Sharma SV, Lee DY, Li B, et al.: A chromatin-mediated reversible drug-tolerant state in cancer cell subpopulations. Cell. 2010, 141:69-80. 10.1016/j.cell.2010.02.027

60. Esteller M, Hamilton SR, Burger PC, Baylin SB, Herman JG: Inactivation of the DNA repair gene O-6methylguanine-DNA methyltransferase by promoter hypermethylation is a common event in primary human neoplasia. Cancer Res. 1999, 59:793-797.

61. Zuber J, Shi J, Wang E, et al.: RNAi screen identifies Brd4 as a therapeutic target in acute myeloid leukaemia. Nature. 2011, 478:524-528. 10.1038/nature10334

62. Iorio MV, Visone R, Di Leva G, et al.: MicroRNA signatures in human ovarian cancer. Cancer Res. 2007, 67:8699-8707. 10.1158/0008-5472.CAN-07-1936

63. Dweep H, Sticht C, Pandey P, Gretz N: miRWalk--database: prediction of possible miRNA binding sites by "walking" the genes of three genomes. J Biomed Inform. 2011, 44:839-847. 10.1016/j.jbi.2011.05.002

64. Comijn J, Berx G, Vermassen P, et al.: The two-handed E box binding zinc finger protein SIP1 downregulates E-cadherin and induces invasion. Mol Cell. 2001, 7:1267-1278. 10.1016/s10972765(01)00260-x

65. Issa JP, Ottaviano YL, Celano P, Hamilton SR, Davidson NE, Baylin SB: Methylation of the oestrogen receptor CpG island links ageing and neoplasia in human colon. Nat Genet. 1994, 7:536-540. 10.1038/ng0894-536

66. Kosaka N, Iguchi H, Yoshioka Y, Takeshita F, Matsuki Y, Ochiya T: Secretory mechanisms and intercellular transfer of microRNAs in living cells. J Biol Chem. 2010, 285:17442-17452. 10.1074/jbc.M110.107821

67. Saito Y, Liang G, Egger G, Friedman JM, Chuang JC, Coetzee GA, Jones PA: Specific activation of microRNA-127 with downregulation of the proto-oncogene BCL6 by chromatin-modifying drugs in human cancer cells. Cancer Cell. 2006, 9:435-443. 10.1016/j.ccr.2006.04.020

68. Carroll JS, Meyer CA, Song J, et al.: Genome-wide analysis of estrogen receptor binding sites. Nat Genet. 2006, 38:1289-1297. 10.1038/ng1901

69. Valk PJ, Verhaak RG, Beijen MA, et al.: Prognostically useful gene-expression profiles in acute myeloid leukemia. N Engl J Med. 2004, 350:1617-1628. 10.1056/NEJMoa040465

70. Weinstein JN, Myers TG, O'Connor PM, et al.: An information-intensive approach to the molecular pharmacology of cancer. Science. 1997, 275:343-349. 10.1126/science.275.5298.343

71. Kantarjian H, Issa JP, Rosenfeld CS, et al.: Decitabine improves patient outcomes in myelodysplastic syndromes: results of a phase III randomized study. Cancer. 2006, 106:1794-1803. 10.1002/cncr.21792 
72. Houseman EA, Accomando WP, Koestler DC, et al.: DNA methylation arrays as surrogate measures of cell mixture distribution. BMC Bioinform. 2012, 13:86. 10.1186/1471-2105-13-86

73. Patel AP, Tirosh I, Trombetta JJ, et al.: Single-cell RNA-seq highlights intratumoral heterogeneity in primary glioblastoma. Science. 2014, 344:1396-1401. 10.1126/science.1254257

74. West M, Blanchette C, Dressman H, et al.: Predicting the clinical status of human breast cancer by using gene expression profiles. P Natl Acad Scad USA. 2001, 98:11462-11467. 10.1073/pnas.201162998

75. Turchinovich A, Weiz L, Langheinz A, Burwinkel B: Characterization of extracellular circulating microRNA. Nucleic Acids Res. 2011, 39:7223-7233. 10.1093/nar/gkr254

76. McCabe MT, Ott HM, Ganji G, et al.: EZH2 inhibition as a therapeutic strategy for lymphoma with EZH2activating mutations. Nature. 2012, 492:108-112. 10.1038/nature11606

77. Dammann R, Li C, Yoon JH, Chin PL, Bates S, Pfeifer GP: Epigenetic inactivation of a RAS association domain family protein from the lung tumour suppressor locus 3p21.3. Nat Genet. 2000, 25:315-319. $10.1038 / 77083$

78. Turcan S, Rohle D, Goenka A, et al.: IDH1 mutation is sufficient to establish the glioma hypermethylator phenotype. Nature. 2012, 483:479-483. 10.1038/nature10866

79. Rhee I, Bachman KE, Park BH, et al.: DNMT1 and DNMT3b cooperate to silence genes in human cancer cells. Nature. 2002, 416:552-556. 10.1038/416552a

80. Lapointe J, Li C, Higgins JP, et al.: Gene expression profiling identifies clinically relevant subtypes of prostate cancer. P Natl Acad Scad USA. 2004, 101:811-816. 10.1073/pnas.0304146101

81. Eckhardt F, Lewin J, Cortese R, et al.: DNA methylation profiling of human chromosomes 6, 20 and 22. Nat Genet. 2006, 38:1378-1385. 10.1038/ng1909

82. Bos PD, Zhang XH, Nadal C, et al.: Genes that mediate breast cancer metastasis to the brain. Nature. 2009, 459:1005-1009. 10.1038/nature08021

83. Iliopoulos D, Hirsch HA, Struhl K: An epigenetic switch involving NF-kappaB, Lin28, Let-7 MicroRNA, and IL6 links inflammation to cell transformation. Cell. 2009, 139:693-706. 10.1016/j.cell.2009.10.014

84. Bracken AP, Dietrich N, Pasini D, Hansen KH, Helin K: Genome-wide mapping of Polycomb target genes unravels their roles in cell fate transitions. Genes Dev. 2006, 20:1123-1136. 10.1101/gad.381706

85. Campo E, Swerdlow SH, Harris NL, Pileri S, Stein H, Jaffe ES: The 2008 WHO classification of lymphoid neoplasms and beyond: evolving concepts and practical applications. Blood. 2011, 117:5019-5032. 10.1182/blood-2011-01-293050

86. Chapman MA, Lawrence MS, Keats JJ, et al.: Initial genome sequencing and analysis of multiple myeloma. Nature. 2011, 471:467-472. 10.1038/nature09837

87. Murakami Y, Yasuda T, Saigo K, Urashima T, Toyoda H, Okanoue T, Shimotohno K: Comprehensive analysis of microRNA expression patterns in hepatocellular carcinoma and non-tumorous tissues. Oncogene. 2006, 25:2537-2545. 10.1038/sj.onc.1209283

88. Gregoretti IV, Lee YM, Goodson HV: Molecular evolution of the histone deacetylase family: functional implications of phylogenetic analysis. J Mol Biol. 2004, 338:17-31. 10.1016/j.jmb.2004.02.006

89. Li QL, Ito K, Sakakura C, et al.: Causal relationship between the loss of RUNX3 expression and gastric cancer. Cell. 2002, 109:113-124. 10.1016/S0092-8674(02)00690-6

90. Ng EK, Chong WW, Jin H, et al.: Differential expression of microRNAs in plasma of patients with colorectal cancer: a potential marker for colorectal cancer screening. Gut. 2009, 58:1375-1381. 10.1136/gut.2008.167817

91. Bibikova M, Barnes B, Tsan C, et al.: High density DNA methylation array with single CpG site resolution. Genomics. 2011, 98:288-295. 10.1016/j.ygeno.2011.07.007

92. Yap KL, Li S, Munoz-Cabello AM, Raguz S, Zeng L, Mujtaba S, Gil J, Walsh MJ, Zhou MM: Molecular interplay of the noncoding RNA ANRIL and methylated histone H3 lysine 27 by polycomb CBX7 in 
93. Suzuki H, Watkins DN, Jair KW, et al.: Epigenetic inactivation of SFRP genes allows constitutive WNT signaling in colorectal cancer. Nat Genet. 2004, 36:417-422. 10.1038/ng1330

94. Esteller M, Silva JM, Dominguez G, et al.: Promoter hypermethylation and BRCA1 inactivation in sporadic breast and ovarian tumors. J Natl Cancer Inst. 2000, 92:564-569. 10.1093/jnci/92.7.564

95. Schlesinger Y, Straussman R, Keshet I, et al.: Polycomb-mediated methylation on Lys27 of histone H3 pre-marks genes for de novo methylation in cancer. Nat Genet. 2007, 39:232-236. 10.1038/ng1950

96. Shimono Y, Zabala M, Cho RW, et al.: Downregulation of miRNA-200c links breast cancer stem cells with normal stem cells. Cell. 2009, 138:592-603. 10.1016/j.cell.2009.07.011

97. Doi A, Park IH, Wen B, et al.: Differential methylation of tissue- and cancer-specific CpG island shores distinguishes human induced pluripotent stem cells, embryonic stem cells and fibroblasts. Nat Genet. 2009, 41:1350-1353. 10.1038/ng.471

98. Esteller M, Sanchez-Cespedes M, Rosell R, Sidransky D, Baylin SB, Herman JG: Detection of aberrant promoter hypermethylation of tumor suppressor genes in serum DNA from non-small cell lung cancer patients. Cancer Res. 1999, 59:67-70.

99. Belinsky SA, Nikula KJ, Palmisano WA, et al.: Aberrant methylation of p16(INK4a) is an early event in lung cancer and a potential biomarker for early diagnosis. P Natl Acad Scad USA. 1998, 95:11891-11896. 10.1073/pnas.95.20.11891

100. Rainier S, Johnson LA, Dobry CJ, Ping AJ, Grundy PE, Feinberg AP: Relaxation of imprinted genes in human cancer. Nature. 1993, 362:747-749. 10.1038/362747a0

\section{Additional Information \\ Disclosures}

Human subjects: All authors have confirmed that this study did not involve human participants or tissue. Animal subjects: All authors have confirmed that this study did not involve animal subjects or tissue. Conflicts of interest: In compliance with the ICMJE uniform disclosure form, all authors declare the following: Payment/services info: All authors have declared that no financial support was received from any organization for the submitted work. Financial relationships: All authors have declared that they have no financial relationships at present or within the previous three years with any organizations that might have an interest in the submitted work. Other relationships: All authors have declared that there are no other relationships or activities that could appear to have influenced the submitted work.

\section{References}

1. Waddington CH: The epigenotype. Int J Epidemiol. 2012, 41:10-13. 10.1093/ije/dyr184

2. Richards EJ: Inherited epigenetic variation--revisiting soft inheritance . Nat Rev Genet. 2006, 7:395-401. 10.1038/nrg1834

3. Feinberg AP, Vogelstein B: Hypomethylation distinguishes genes of some human cancers from their normal counterparts. Nature. 1983, 301:89-92. 10.1038/301089a0

4. Feinberg AP, Tycko B: The history of cancer epigenetics. Nat Rev Cancer. 2004, 4:143-153. 10.1038/nrc1279

5. Jones PA, Baylin SB: The epigenomics of cancer. Cell. 2007, 128:683-692. 10.1016/j.cell.2007.01.029

6. Van Noorden R, Maher B, Nuzzo R: The top 100 papers. Nature. 2014, 514:550-553. 10.1038/514550a

7. Wrafter PF, Connelly TM, Khan J, Devane L, Kelly J, Joyce WP: The 100 most influential manuscripts in colorectal cancer: A bibliometric analysis. Surgeon. 2016, 14:327-336. 10.1016/j.surge.2016.03.001

8. Uysal E: Top 100 cited classic articles in breast cancer research . Eur J Breast Health. 2017, 13:129-137.

9. Powell AG, Hughes DL, Brown J, Larsen M, Witherspoon J, Lewis WG: Esophageal cancer's 100 most influential manuscripts: a bibliometric analysis. Dis Esophagus. 2017, 30:1-8. 10.1093/dote/dow039

10. Guglielmi G: Wikipedia's top-cited scholarly articles - revealed. Nature. 2018, 557:291-292. 10.1038/d41586018-05161-6

11. Golub TR, Slonim DK, Tamayo P, et al.: Molecular classification of cancer: class discovery and class prediction by gene expression monitoring. Science. 1999, 286:531-537. 10.1126/science.286.5439.531

12. Dohner H, Estey EH, Amadori S, et al.: Diagnosis and management of acute myeloid leukemia in adults: recommendations from an international expert panel, on behalf of the European LeukemiaNet. Blood. 2010, 115:453-474. 10.1182/blood-2009-07-235358

13. Mrozek K, Marcucci G, Nicolet D, et al.: Prognostic significance of the European LeukemiaNet standardized system for reporting cytogenetic and molecular alterations in adults with acute myeloid leukemia. J Clin Oncol. 2012, 30:4515-4523. 10.1200/JCO.2012.43.4738

14. Papaemmanuil E, Gerstung M, Bullinger L, et al.: Genomic classification and prognosis in acute myeloid leukemia. N Engl J Med. 2016, 374:2209-2221. 10.1056/NEJMoa1516192

15. Adorjan P, Distler J, Lipscher E, et al.: Tumour class prediction and discovery by microarray-based DNA 
methylation analysis. Nucleic Acids Res. 2002, 30:e21. 10.1093/nar/30.5.e21

16. Eden A, Gaudet F, Waghmare A, Jaenisch R: Chromosomal instability and tumors promoted by DNA hypomethylation. Science. 2003, 300:455. 10.1126/science.1083557

17. Greger V, Passarge E, Hopping W, Messmer E, Horsthemke B: Epigenetic changes may contribute to the formation and spontaneous regression of retinoblastoma. Hum Genet. 1989, 83:155-158. 10.1007/bf00286709

18. Hansen RS, Gartler SM: 5-Azacytidine-induced reactivation of the human X chromosome-linked PGK1 gene is associated with a large region of cytosine demethylation in the 5'CpG island. P Natl Acad Scad USA. 1990, 87:4174-4178. 10.1073/pnas.87.11.4174

19. Herman JG, Latif F, Weng Y, et al.: Silencing of the VHL tumor-suppressor gene by DNA methylation in renal carcinoma. P Natl Acad Scad USA. 1994, 91:9700-9704. 10.1073/pnas.91.21.9700

20. Toyota M, Ahuja N, Ohe-Toyota M, Herman JG, Baylin SB, Issa JP: CpG island methylator phenotype in colorectal cancer. P Natl Acad Scad USA. 1999, 96:8681-8686. 10.1073/pnas.96.15.8681

21. Buschhausen G, Wittig B, Graessmann M, Graessmann A: Chromatin structure is required to block transcription of the methylated herpes simplex virus thymidine kinase gene. P Natl Acad Scad USA. 1987, 84:1177-1181. 10.1073/pnas.84.5.1177

22. Keshet I, Lieman-Hurwitz J, Cedar H: DNA methylation affects the formation of active chromatin . Cell. 1986, 44:535-543. 10.1016/0092-8674(86)90263-1

23. Laird PW: The power and the promise of DNA methylation markers . Nat Rev Cancer. 2003, 3:253-266. 10.1038/nrc1045

24. Hulbert A, Jusue-Torres I, Stark A, et al.: Early detection of lung cancer using DNA promoter hypermethylation in plasma and sputum. Clin Cancer Res. 2017, 23:1998-2005. 10.1158/1078-0432.CCR-161371

25. Bailey VJ, Easwaran H, Zhang Y, et al.: MS-qFRET: a quantum dot-based method for analysis of DNA methylation. Genome Res. 2009, 19:1455-1461. 10.1101/gr.088831.108

26. Li M, Chen WD, Papadopoulos N, et al.: Sensitive digital quantification of DNA methylation in clinical samples. Nat Biotechnol. 2009, 27:858-863. 10.1038/nbt.1559

27. International Cancer Genome Consortium, Hudson TJ, Anderson W, et al.: International network of cancer genome projects. Nature. 2010, 443:993-998. 10.1038/nature08987

28. Bernstein BE, Stamatoyannopoulos JA, Costello JF, et al.: The NIH Roadmap Epigenomics Mapping Consortium. Nat Biotechnol. 2010, 28:1045-1048. 10.1038/nbt1010-1045

29. Garfield E: "Science Citation Index" - a new dimension in indexing . Science. 1964, 144:649-654. 10.1126/science.144.3619.649

30. Gama-Sosa MA, Slagel VA, Trewyn RW, Oxenhandler R, Kuo KC, Gehrke CW, Ehrlich M: The 5methylcytosine content of DNA from human tumors. Nucleic Acids Res. 1983, 11:6883-6894. 10.1093/nar/11.19.6883 